\title{
Potentials of two varieties of cashew apple pulp as feedstuff for ruminants
}

${ }^{* 1}$ Okpanachi, U., ${ }^{2}$ Agu, C. I., Igoche, L.E. and ${ }^{1}$ Oyedapo, F.A

${ }^{I}$ Department of Animal Production, Faculty of Agriculture, University of Jos, Plateau State, Nigeria.

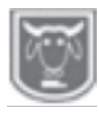

Abstract
${ }^{2}$ Department of Animal Health and Production Technology,

Enugu State Polytechnic, Iwollo, Enugu State, Nigeria.

Corresponding author: ucheleokpanachi@gmail.com or okpanachiu@unijos.edu.ng ; +2348034377953

The study was aimed at assessing the effects of two varieties of cashew (Anacardium occidentale) apple pulp as feedstuff for ruminants. Samples of the yellow and red varieties of cashew apple pulp were collected, processed and analysed for mineral, crude fiber fraction and $\mathrm{pH}$. Results showed that sodium value in red variety was significantly higher $(P<0.05)$ than that of the yellow variety. Potassium value in red variety was significantly higher $(P<0.01)$ than that of the yellow variety. Values for calcium, magnesium, and phosphorus in the yellow variety were significantly higher $(P<0.01)$ than those of the red variety. Values for cellulose, hemicelluloses and neutral detergent fibre in the red variety were significantly higher $(P<0.01)$ than those of the yellow variety. Acid Detergent Lignin value for the yellow variety was significantly higher $(P<0.01)$ than that of the red variety. Values for acid detergent fibre, crude protein, carbohydrate and $\mathrm{pH}$ were not significantly affected $(P>0.05)$. Yellow cashew apple pulp from the results of this study is richer in minerals when compared to the red variety. Results from the crude fibre fraction suggest that the yellow cashew apple pulp variety may have a better digestibility when compared to the red variety. Although the values of the various parameters from the 2 varieties show that they are fit to be used as feeding stuff for ruminants, the yellow variety appears to be better on the general basis.

Keywords: Cashew apple pulp, Mineral, Crude fibre fraction, $\mathrm{pH}$, Varieties, ruminants

\section{Introduction}

Cashew apple (Anacardium occidentale L.) is a fruit peduncle, also called pseudo-fruit (Akinwale 2000; Assunção and Mercadante 2003). Cashew apple juice, a very popular juice in Brazil with an estimated production of 200 million liters per year, is rich in vitamin $\mathrm{C}$ and minerals (sodium, potassium, phosphorus, chloride and magnesium). Cancer prevention, antimicrobial activity against the bacteria Helicobacter pylori, which causes gastric diseases, and antioxidant properties have been reported for this tropical fruit (Sampaio 1990; Kubo et al., 1999; Wharta et al., 2004). Cashew is one of the most important plantation crops in India, Brazil, Nigeria and Vietnam (Muniz et al., 2006) and Kogi State is the largest cashew producing state in Nigeria (Okpanachi et al., 2016a; 2016b; 2016c). Unlike cashew nut kernel, which has an indisputably exclusive fine taste and a commercial attractiveness of its own, cashew "apple," despite its high nutritive values (high content of vitamin $\mathrm{C}$ and minerals, i.e., $\mathrm{Ca}$, $\mathrm{P}, \mathrm{Fe}$ ) is less attractive (Ogunmoyela, 1983; Moura, 1998). It is rich in Vitamin C than oranges and contains high amount of mineral salts (Deckers et al., 2001; Denise et al., 2002). The cashew apple is very rich in vitamin C (262 mg/100 mL of juice) and contains five times more vitamin $\mathrm{C}$ than orange. A glass of cashew apple juice meets an adult individual's daily vitamin $\mathrm{C}$ (30 $\mathrm{mg}$ ) requirement (Azam-Ali and Judge, 
2001). The cashew apple or pulp is also a rich source of minerals and other essential nutrients (Deckers et al., 2001). The cashew apple is also rich in sugars and contains considerable amounts of tannins and minerals, mainly calcium, iron and phosphorous. Furthermore, the fruit has medicinal properties. It is used for curing scurvy and diarrhoea and it is effective in preventing cholera. It is applied for the cure of neurological pain and rheumatism. It is also regarded as a first-class source of energy. When fermented with appropriate enzymes, it produces very valuable beverage drinks. Besides its kernel and pulp, other alternative end use to process cashew into include cashew nut shell liquid (CNSL) from which many products can be derived such as paints, plastics, printing ink, wood preservative, insecticide, aviation fuels, water-proof compounds, and anti fade agent in brake-lining (Azam-Ali and Jugde, 2001). When these fruits (pulp) are dried, they turn brown due to the effect of heat on them and these can be incorporated in animal feed since it is in abundance in the study area and often times left to constitute environmental pollution (Okpanachi et al., 2016b). The inclusion of sun-dried yellow cashew pulp to the level of $30 \%$ in the diet of West African dwarf goats provided a cheaper source of feed and also help to reduce environmental pollution, since the pulp, unlike the seed is left to waste during its season. (Okpanachi et al., 2016a and 2016c). The main objective of this study was to assess the potentials of both the red and yellow varieties of cashew apple pulp in regards to the mineral, $\mathrm{pH}$ and crude fibre fraction, as what already exist in literature either talks about the yellow variety alone or just about cashew pulp, without putting the variety into consideration.

\section{Materials and methods}

Procurement and preparation of varieties

\section{of cashew pulp}

Samples of the 2 main varieties of cashew pulp (red and yellow) were obtained from Anyigba and its environs. Known weights were sun dried to determine the dry matter (DM). They were washed, sliced with the aid of knives and chopping boards into bits, air-dried and moved to the glass house where they were properly dried. The dried cashew pulp were packaged, weighed and stored in a safe place. The dried cashew pulp was milled packaged and then sent to the laboratory for analysis.

\section{Mineral analysis}

Analysis of dried cashew pulp for minerals such as calcium, phosphorus, sodium, magnesium and potassium were determined using the methods described by Udo et al. (2009) and Ibitoye (2005).

\section{Crude fibre fraction analysis}

Samples of the two major varieties of cashew pulp were dried and milled and were analysed for Neutral detergent fibre (NDF), Acid detergent fibre (ADF) and Acid detergent lignin (ADL), according to Van Soest and Robertson (1980) while the values of cellulose and hemicelluloses were obtained by calculation using these formulas; Hemicellulose $=\mathrm{NDF}-\mathrm{ADF}$ and Cellulose $=\mathrm{ADF}-\mathrm{ADL}$.

Experimental design and statistical analysis

Completely randomized design was used. Data obtained were subjected to Analysis of Variance (ANOVA) and means that were significantly different were separated using Least Significant Difference (LSD), both contained in SPSS for Window, version 16.

\section{Result}

Some minerals in sun-dried cashew pulp

Results showed that sodium and potassium in the red variety $(0.0663$ and 1.0787$)$ were significantly higher $(\mathrm{P}<0.05 / \mathrm{P}<0.01)$ than 0.0613 and 0.9133 for sodium and potassium respectively in the yellow 


\section{Okpanachi, Agu, Igoche and Oyedapo}

variety. Calcium, magnesium and phosphorus in the yellow variety $(0.1840$, 0.1403 and 0.1250$)$ were however significantly higher $(\mathrm{P}<0.01)$ than 0.1473 ,
0.1117 and 0.1043 for calcium, magnesium and phosphorus respectively in the red variety.

Table 1: Some minerals in sun-dried cashew pulp

\begin{tabular}{lccl}
\hline \multicolumn{3}{c}{ Varieties of cashew } \\
\hline Minerals (\%) & Yellow & Red & SEM \\
\hline Sodium & $0.0613^{\mathrm{b}}$ & $0.0663^{\mathrm{a}}$ & $0.0013^{*}$ \\
Potassium & $0.9133^{\mathrm{b}}$ & $1.0787^{\mathrm{a}}$ & $0.0370^{* *}$ \\
Calcium & $0.1840^{\mathrm{a}}$ & $0.1473^{\mathrm{b}}$ & $0.0082^{* *}$ \\
Magnesium & $0.1403^{\mathrm{a}}$ & $0.1117^{\mathrm{b}}$ & $0.0065^{* *}$ \\
Phosphorus & $0.1250^{\mathrm{a}}$ & $0.1043^{\mathrm{b}}$ & $0.0047^{* *}$ \\
\hline a, b $=$ Means with different superscripts on the same row are significantly different.
\end{tabular}

$\mathrm{SEM}=$ Standard Error of Mean, $*=$ Significant at $(\mathrm{P}<0.05) \quad * *=$ Significant at $(\mathrm{P}<0.01)$.

Effect of variety on cellulose, hemicellulose, NDF, ADF, ADL and $\mathrm{pH}$ of sun-dried cashew pulp meal

The effect of variety on cellulose, hemicellulose, NDF, ADF, ADL, crude protein, carbohydrate and $\mathrm{pH}$ of sun-dried cashew pulp meal is presented in Table 2. Results for cellulose, hemicellulose, NDF and ADL were significantly affected $(\mathrm{P}<$ 0.01 ) by the varieties. Results for ADF, crude protein, carbohydrate and $\mathrm{pH}$ were however, not significantly affected $(\mathrm{P}>$ 0.05 ) by the varieties. The values for cellulose, hemicellulose and neutral detergent fibre in the red variety (13.30, 25.57 and 62.53) were significantly higher $(\mathrm{P}<0.01)$ than 3.97, 19.39 and 56.13 for cellulose, hemicellulose and neutral detergent fibre respectively in the yellow variety. The value for acid detergent lignin in the yellow variety (32.77) was however significantly higher $(\mathrm{P}<0.01)$ than 24.16 for acid detergent lignin in the red variety.

Table 2: Effect of variety on cellulose, hemicellulose, NDF, ADF, ADL and $\quad$ pH of sun $\quad$-dried cashew pulp meal

\begin{tabular}{lccc}
\hline \multicolumn{1}{c}{ Varieties of cashew } \\
\hline Components (\%) & Yellow & Red & SEM \\
\hline Cellulose & $3.97^{\mathrm{b}}$ & $13.30^{\mathrm{a}}$ & $2.31^{* *}$ \\
Hemicellulose & $19.39^{\mathrm{b}}$ & $25.57^{\mathrm{a}}$ & $1.42^{* *}$ \\
Neutral Detergent Fibre & $56.13^{\mathrm{b}}$ & $62.53^{\mathrm{a}}$ & $1.43^{* *}$ \\
Acid Detergent Fibre & 36.74 & 36.96 & $0.30^{\mathrm{ns}}$ \\
Acid Detergent Lignin & $32.77^{\mathrm{a}}$ & $24.16^{\mathrm{b}}$ & $1.93^{* *}$ \\
Crude protein & 13.82 & 16.96 & $0.93^{\mathrm{ns}}$ \\
Carbohydrate & 54.79 & 52.28 & $1.44^{\mathrm{ns}}$ \\
pH & 4.60 & 4.22 & $0.13^{\mathrm{ns}}$ \\
\hline
\end{tabular}

$\mathrm{a}, \mathrm{b}=$ Means with different superscripts on the same row are significantly different $(\mathrm{P}<0.01)$

$\mathrm{SEM}=$ Standard Error of Mean, $* *=$ Significant at $(\mathrm{P}<0.01), \mathrm{ns}=$ not significant.

\section{Discussion}

Effect of cashew varieties on selected mineral compositions of sun-dried cashew pulp

The value of sodium for sun-dried red cashew pulp was higher than that of the yellow variety. Armah (2011) reported 0.56 $\%$ as value for sodium in sun-dried cashew meal. The value of potassium for sun-dried red cashew pulp was higher than that of the yellow variety. Armah (2011) reported 1.65 $\%$ as value for potassium in sun-dried cashew meal. The value of calcium for sundried yellow cashew pulp was higher than that of the red variety. Adebowale et al. (2011) reported $0.21 \%$ as value for calcium 


\section{Mineral, crude fibre compositions and pH of yellow and red varieties of cashew apple pulp}

in sun-dried cashew meal. Armah (2011) reported $0.72 \%$ as value for calcium in sundried cashew meal. The value of magnesium for sun-dried yellow cashew pulp was higher than that of the red variety. The value of phosphorus for sun-dried yellow cashew pulp was significantly higher $(\mathrm{P}<0.01)$ than that of the red variety. Armah (2011) reported $0.60 \%$ as value for phosphorus in sun-dried cashew meal; whereas Adebowale et al. (2011) reported $0.26 \%$ as phosphorus content in dried cashew pulp. The difference between the mineral content obtained in this study and those reported by Adebowale et al. (2011) and Armah (2011) may be due to the difference in handling and processing, storage, environment, etc. The result on mineral composition agreed with the study of Deckers et al. (2001) and Denise et al. (2002), that cashew contains high amount of mineral salts.

\section{Effect of cashew variety on cellulose, hemicellulose, NDF, ADF, ADL and $\mathrm{pH}$ of sun-dried cashew pulp meal}

The cellulose, hemicellulose, NDF and ADL were affected by the varieties, implying that there were differences in cellulose, hemicellulose, NDF and ADL among the treatments. There were no difference in ADF among the treatments; however values of cellulose, hemicelluloses and NDF for the sun-dried red cashew pulp meal were higher than those of the sun-dried yellow cashew pulp meal. The value of ADL for the sun-dried yellow cashew pulp meal was however higher than that of sun-dried red cashew pulp meal. These differences in nutritive values may be due to varietal difference (sun-dried yellow and red cashew pulp meal), the type of soil (environment) on which the cashew were grown and the stage of maturity at which the cashew were harvested. The values of $18.31 \%-31.50 \%$,
$19.30 \%-27.18 \%$ and $23.91 \%-32.21 \%$ were reported by Dos Santos Lima et al. (2012) for cellulose, hemicelluloses and lignin of dried cashew pulp respectively. The values $(3.97 \%$, for sun-dried yellow cashew pulp meal and $13.30 \%$, for sundried red cashew pulp meal) of cellulose in this study are lower than that reported by Dos Santos Lima et al. (2012). The values of hemicelluloses $(19.39 \%$, for sun-dried yellow cashew pulp meal and $25.57 \%$, for sun-dried red cashew pulp meal) and lignin (24.16\%, for sun-dried red cashew pulp meal $-32.77 \%$, for sun-dried yellow cashew pulp meal) obtained in this study are however very close to those reported by Dos Santos Lima et al. (2012). Kalio et al. (2013) reported $5.63 \%$ and $1.95 \%$ for $\mathrm{ADF}$ and ADL of Yam; $32.85 \%$ and $10.20 \%$ for ADF and ADL of cassava; $7.64 \%$ and $1.95 \%$ for $\mathrm{ADF}$ and $\mathrm{ADL}$ of sweet potato and $13.70 \%$ and $5.90 \%$ for $\mathrm{ADF}$ and $\mathrm{ADL}$ of ripe plantain respectively. Okoruwa and Adewumi (2010) reported $57 \%, 27 \%$ and $26 \%$ for $\mathrm{NDF}, \mathrm{ADF}$ and $\mathrm{CF}$ of Dried pineapple pulp.

The $\mathrm{pH}$ value 4.22 (sun-dried red cashew pulp meal) and 4.60 (sun-dried yellow cashew pulp meal) obtained in this study is higher than 4.1 reported by La Van Kinh et al. (1997) and 4.11 reported by Oliveira (1999). Although the $\mathrm{pH}$ value in this study was not affected by variety, the red variety is slightly more acidic since it had a $\mathrm{pH}$ of 4.22 compared to the yellow variety with a $\mathrm{pH}$ of 4.6. This is however not in agreement with Adou et al. (2012) who reported a $\mathrm{pH}$ of 4.47 and 4.4 for cashew juice from red and yellow cashew variety, respectively.

\section{Conclusion}

In conclusion, it was observed that the red variety is richer in sodium and potassium while the yellow variety is richer in calcium, magnesium and phosphorus. The red variety also recorded the highest values for 


\section{Okpanachi, Agu, Igoche and Oyedapo}

cellulose, hemicelluloses and acid detergent fibre while the yellow variety recorded the highest value for acid detergent lignin. The red variety may be said to be more acidic when compared to the yellow variety. From the results of this study it can be concluded that the yellow variety recoded the overall best performance

\section{References}

Adebowale, B. A., Olubamiwa, O. and Ogunjobi, M. A. K. 2011. Substitution value of sun-dried cashew apple bagasse in the diets of Clarias gariepinus. InternationalResearch Journal of Agricultural Science and Soil Science 1(7):268-272. Available online http://www. interesjournals. org/IRJAS.

Adou, M., Tetchi, F. A., Gbané, M., Kouassi, K. N. and Amani, N. G. 2012. Physico- c h e m i c a l characterization of cashew apple Juice (Anacardium occidentale, 1.) From yamoussoukro (côte d'ivoire). Innovative Romanian Food Biotechnology 11: 32-43

Akinwale, T. O. 2000. Cashew apple juice: Its use in fortifying the nutritional quality of some tropical fruits. Eur. Food Res. Technol. 211:205-207.

Assunção, R. B. and Mercadante, A. Z. 2003. Carotenoids and ascorbic acid composition from commercial products of cashew apple (Annacardium occidentale L.) J. Food Compos. Anal. 16: 647-657.

Armah, I. N. A. 2011. The effect of starter-grower pigs fed diets containing varying levels of dried cashew (Anarcadium occidentale 1.) pulp (DCP). A thesis submitted to the School of Graduate Studies Kwame
Nkrumah University of Science and Technology, Kumasi, in partial fulfillment of the requirement for the award of the degree, Master of Science in Animal Nutrition, 2008 h t t p : / / h d l. ha n d le. net/123456789/81.

Azam-Ali, S. H. and Judge, E. C. 2001. Small-scale cashew nut p r o c e s s i ng. I T D G Schumacher Centre for Technology and Development Bourton on Dunsmore, Rugby, Warwickshire, UK.

Deckers, J., Cundall, S. H., Ngatunga, A and Bassi, G. 2001. Cashew Crop Production in Tropical Africa. Romain H. Reamaekers (Ed). Directorate General for Internationl Cooperation (DGIC) Publisher, Brussels, Belgium. Pp 236-238.

Denise, C. P. O., Santos, A. S., Blumenberg, D. W., Matta, V. M., Cabral, L. M. C and Couri, S. 2002. Cashew Apple Juice Stabilization by microfiltration. Desalination 148:61-65.

Dos Santos Lima, F. C., Honorato da Silva, F. L., Palmeira Gomes, J and Da Silva Neto, J. M. 2012. Chemical Composition of the Cashew Apple Bagasse and Potential Use for Ethanol Production. Advances in Chemical Engineering and Science, 2012, 2: 519-523 doi:10.4236/aces.2012 .24064 (http://www.SciRP.org/journal/ace s).

Ibitoye A. A. 2005. Laboratory manual on basis methods in plant analysis. Concept I $\mathrm{T}$ and Educational Consults. Akure, Nigeria. Pp 5558. 
Kalio, G. A., Ayuk, A. A. and Agwunobi, L. N. 2013. Performance and economics of production of West African Dwarf (WAD) bucks fed crop by-products as sole feed in Cross River State, Nigeria. World Journal of Agricultural Sciences $1\left(\begin{array}{lllllllll}3 & ) & 0 & 0 & 8 & 1 & 0 & 8 & 7\end{array}\right.$. http://wsrjournals.org/journal/wja S.

Kubo, J., Lee, J. R. and Kubo, I. 1999. Anti-Helicobacter pylori agents from the cashew apple. J. Agric. Food Chem. 47, 533-537.

La Van Kinh, Vu Van Do and Dang Duc Phuong 1997. Chemical composition of cashew apple waste ensiled with poultry litter. Livestock Research for Rural Development (9) 1 : http://www.cipav.org. co/lrrd /lrr d9/1/kinh91.htm.

Moura, C. F. H. 1998. Qualidade de pedúnculos de clones de cajueiro anãoprecoce (Anacardium occidentale L. var. nanum) irrigados. Master's Thesis, Universidade Federal do Ceará, Fortaleza, Brazil.

Muniz, C. R., Borges, M. D. F. and Freire, F. D. C. O. 2006. Tropical and subtropical fruit fermented beverages. In Microbial Biotechnology in Horticulture Vol. 2; (R.C. Ray and O.P. Ward, eds.), in press, Science Publishers, Enfield, $\mathrm{NH}$.

Oliveira, M. E. B. D. 1999. Physico chemical parameters evaluation of acerola, yellow mombin and cashew apple frozen pulps. Ciênc. Tecnol. Aliment. [online]. 1999. 19(3): 326-332. ISSN 1678$\begin{array}{llll}4 & 5 & 7 & \mathrm{X}\end{array}$. http://dx.doi.org/10.1590/S0101-
20611999000300006

Ogunmoyela, O. A. 1983. Prospects for cashew "apple" processing and utilization in Nigeria. Process Biochem. March/April, 6-7.

Okoruwa, M. I. and Adewumi, M. K. 2010. Effect of replacing Panaicum maximum with dried pineapple pulp on nutrient digestibility and nutrient balance of WAD sheep. Nigerian Journal of Animal Science 12: 103 -109.

Okpanachi, U, Ayoade, J. A. and Tuleun, C. D. 2016 a. Carcass Characteristics, Internal Organs and Economics of Feeding SunDried Yellow Cashew Pulp Based Diets to West African Dwarf Goats. Animal and Veterinary Sciences. Special Issue: Academic Research for Multidisciplinary. 4 $(3-1)$ : 1 - 6. d o i : 10.11648/j.avs.s. 2016040301.11

Okpanachi, U, Attah, S and Oyewole, B. O. 2016b. Effects of varieties of dried cashew pulp on in vitro fermentation parameters and volume of gas produced at different incubation time. Agriculture \& Food, Journal of International Scientific Publications, 4: 530 - 536 www.scientific-publications.net

Okpanachi, U., Oyewole, B. O., Egbu, C. F., Ganiyu, O. Y. 2016c. Effects of Feeding Sun-Dried Yellow Cashew Pulp Based Diets on Performance, Dry Matter and Nutrient Digestibility of West African Dwarf Goats. Animal and Veterinary Sciences. Special Issue: Issue I: Foundations of Hadronic Mathematics. 4 (3-1): 7 12 d o i : 10.11648/j.avs.s.2016040301.12

Sampaio, T. M. T. 1990. Estudo dos sucos 


\section{Okpanachi, Agu, Igoche and Oyedapo}

límpidos simples, concentrado e reconstituido de caju Anacardium occidentale L. Master Dissertation, p. 172, Universiade Federal do Ceará, D e parta m e n t o d e Tecnologia de Alimentos, Fortaleza, Brazil.

Udo, E. J., Ibia, T. O., Ogunwale, J. A., Ano, A. O and Esu, I. E. 2009. Manual of soil, plant and water analyses. Sibon Books Limited, Lagos.

Van Soest, P. J and Robertson, J. B. 1980.

Systems of analysis for evaluating fibrous feeds. Ed. Pigon, M.J and Mcgraham T. Workshop proceedings on Standardisation of Analytical Methodology for feeds, Ottawa, Canada. pp 135-143.
Wharta, E. S. A., Moreira, A. V. B. and Mancini, J. 2004. Identificação e atividade antioxidante dos principais compostos fenólicos presentes no suco e na castanha do caju. Anais do XIX Congresso Brasileiro de Ciência e Tecnologia de Alimentos - Estratégia para o Desenvolvimento, Recife, $P E$, Brazil.

Received: $10^{\text {th }}$ September, 2018 Accepted: $21^{\text {st }}$ December, 2018 